\title{
Archaic sanctuaries in Umbria
}

Monsieur Guy Bradley

\section{Citer ce document / Cite this document :}

Bradley Guy. Archaic sanctuaries in Umbria. In: Cahiers du Centre Gustave Glotz, 8, 1997. pp. 111-129;

doi : https://doi.org/10.3406/ccgg.1997.1436

https://www.persee.fr/doc/ccgg_1016-9008_1997_num_8_1_1436

Fichier pdf généré le 13/05/2018 


\section{ARCHAIC SANCTUARIES IN UMBRIA}

The typical Umbrian sanctuary of the archaic period (which I use here to mean the sixth, fifth and fourth centuries $\mathrm{BC}$ ) was situated on the peak of one of the large mountains that rear over every Umbrian valley and basin ${ }^{1}$. The rituals that took place there involved what is probably the most distinctive product of Umbrian culture, bronze figurines, vast numbers of which have found their way into the museums and private collections of Italy and indeed of the rest of western and eastern Europe ${ }^{2}$. Whilst concentrated on the area of the sixth Augustan region of Umbria, these types of bronzes have been found in neighbouring areas of central Italy as well. In fact cult sites in "Sabine territory " to the south, such as Ancarano di Norcia, and in "Etruscan territory" to the north west, such as Pasticcetto di Magione on the shores of Lake Trasimene, often show such similarities that it is pointless not to include them in our discussion ${ }^{3}$.

In this article I will discuss the following issues :

I) the source material at our disposal and its problems

II) the evidence for cult activity (sanctuary structures and votives)

III) the relationship of sanctuaries to the pattern of settlement in Umbria

IV) the significance of the creation of cult places of this type for the organisation of society

V) the development of cult sites after the Roman conquest.

'I use sanctuary as the equivalent of "cult site " in this article, with no specific structural implications.

I would like to thank Michael Crawford, Emmanucle Curti, Christopher Smith, Jennifer Stewart and Fay Glinister for reading and commenting on this article, and the School of History and Archacology, University of Wales Cardiff for a research grant aiding publication.

${ }^{2}$ Recent catalogues documenting the Gens antiquissima Italiae exhibition of Umbrian antiquities have included material held by the museums of Budapest and Cracow, for instance ; Umbrian material in private hands in Switzerland features, in J. Chamay et al., L'Art des Peuples Italiques 3000 à 300 avant J.-C. Exhibition catalogue (Geneva-Naples, 1993).

${ }^{3}$ Especially as they often provide precious data from their excavations, and we know so little about the ethnic boundaries of Umbria in this period (which may not have been particularly sharp). This article concentrates on the part of Umbria west of the Appennine watershed. All the sites mentioned are marked on maps 1 and 2 . 


\section{Sources}

Of the large number of cult sites in this part of central Italy, almost all are known through archaeological evidence. The availability of this evidence for study has greatly improved in the last fifteen years, with the publication of the results of new excavations at M. Ansciano, M. Acuto, Grotta Bella, Pasticcetto di Magione and Ancarano di Norcia ${ }^{4}$. Other material, already known, has been presented, often for the first time, in a series of recent articles and catalogues ${ }^{5}$. Nevertheless there are still certain difficulties with the source material. At most of the recently excavated sites the stratigraphy had been damaged by the activity of " clandestini " (particularly at Ancarano, first excavated in 1873). Much of our information still comes from casual finds or from earlier excavations. The latter go back as far as the eighteenth century, and are on the whole poorly documented ; the material found was on most occasions dispersed, going into private collections (some of which subsequently entered museums), and onto the open market.

Most sanctuaries are only identified through the presence of votive material, especially that of bronze figurines. The sanctuaries themselves were usually of dry-stone construction which has tended to be weathered to invisibility ; dating can normally only be established through the typology of the associated material. Where excavation has taken place, the associated votive material is usually found either scattered across the enclosure or buried in votive deposits. Much other material has been discovered casually on the surface or dug up by agricultural and other work. These finds tend to be small in number : they could indicate the presence of significant amounts of other votive material, or they could be merely isolated pieces". The fortuitous circumstances of most discoveries, combined with the lack of provenance for most of the votive material preserved in museums and collections, must mean that the cult sites of which we know represent only a selection of those that once existed.

Epigraphic evidence is extremely sparse for cult activity in the archaic period. Only a small number of votive objects with Umbrian inscriptions have

+ M. Ansciano : C. Malone and S. Stoddart (eds.), Territory, Time and State, Cambridge, 1994 ; M. Acuto : L. Cenciaioli, Il santuario di Monte Acuto di Umbertide in M. Corbucci and S. Pettine (eds.), Antichità dall'Umbria a New'York, Exhibition catalogue, Perugia, 1991, 211-26; Umbri ed Etruschi. Genti di confine a Monte Acuto e nel territorio di Umbertide, Exhibition cataloguc (Forthcoming) ; Grotta Bella : I). Monacchi, Nota sulla stipe votiva di Grotta Bella, in SE, 54, 1986, 75-99 ; Pasticcetto di Magione : P. Bruschetti, Il santuario di Pasticcetto di Magione e $i$ votivi in bronzo, in M. Corbucci, S. Pettine (eds.), Gens antiquissima Italiae : Antichità dall'Lmbria a Budapest e Cracovia, Exhibition catalogue, Perugia, 1989, 113-23 ; Ancarano di Norcia : F. Schippa, Il deposito "otilo di Ancarano di Norcia, in Nuovi quaderni dell'Istituto di archeologia dell'università di Perugia. Studi in honore di F: Magi, 1, 1979, 201-27 ; 1). Manconi, M. Dc Angclis, Il santuario di Ancarano di Norcia, in DitA, 5, 1, 1987, 17-28.

5 Such as D. Monacchi, I resti della stipe votiva del Monte Subasio di Assisi (Colle S. Rufino), in $S E, 52,1984,77-89$, and the material in the Gens antiquissima Italiae exhibition catalogues.

"An individual bronze figurine was found in a grave at Cesi for instance (Bull. Inst., 1881, 21.3; (;. Colonna, Bronzi uotivi umbro-sabellici a figura umana. I. Periodo " arcaico ", Florence, 1970, no. 233). 
been found. In the early 1960 s four bronze plates were discovered in association with votive material scattered across the sanctuary site at Colfiorito, which recorded dedications to the goddess Cupra ${ }^{7}$. At Monte Santo outside Todi the "Mars of Todi " had the name of its dedicator inscribed on it in Umbrian ; another smaller bronze statuette, also associated with the sanctuary of Monte Santo, has what appears to be another short Umbrian inscription on it $^{8}$. Beside these few examples, the absence of written material within the mass of votive deposits known to us is quite striking". A few other Umbrian inscriptions dating to the third and second centuries contain what are probably dedications in the context of cults, but whose provenance cannot be firmly linked to sanctuary sites : these include another dedication to Cupra from Fossato di Vico and a dedication to "Iovia " from near Amelia, speculatively connected to the remains of a temple at S. Maria in Canale by Ciotti ${ }^{10}$.

These are, of course, dwarfed by the Iguvine Tables, which seem to provide us with a detailed account of rituals carried out for the community of Iguvium (Gubbio) and in association with the "Atiedian Brothers". The Tables were probably inscribed between the late third and early first centuries $\mathrm{BC}$, but this is only a terminus ante quem for the rituals they record. The exact meaning of the text is extremely controversial ; some parts are better understood than others, and much of the content remains obscure. It remains difficult to directly relate the rites of the Tables, which probably centre around the sacrifice of animals with numerous supplementary offerings of wine, cakes and other foodstuffs, to the archaeological evidence we have of cult practice in this region ${ }^{11}$.

\section{The evidence for cult activity}

Cult sites in Umbria are found in a variety of positions before the Roman conquest. Most are related to features of the landscape. The commonest settings are mountain peaks. These might be the highest points in their vicinity, such as $M$. Pennino, M. Torre Maggiore, M. Maggiore and M. San Pancrazio. Others are on slightly lower peaks, still generally around $1,000 \mathrm{~m}$ in height, such as M. Ansciano, M. Ingino, M. Acuto and Colle San Rufino (a spur of M. Subasio). Other natural features had cult places associated with them, including the cave at Grotta Bella and the edge of a (now drained) lake at Colfiorito, on a major pass over the Appennines into the Picene

7 P. Poccetti, Nuovi documenti italici a complemento del manuale di E. Vetter, Pisa, 1979 [abbreviated as Pol, 2 ; G. Rocca, Iscrizioni umbre minori, Florence, 1996.

${ }^{8}$ Mars of Todi : E. Vetter, Handbuch der italischen Dialekte, Heidelberg, 1953 [abbreviated as Ve], 230 ; Colonna, Bronzi votivi, no. 188 on the Monte Santo figurine (of uncertain authenticity).

"This strongly contrasts with the prominence of written dedications in the shrines at the sources of the Clitumnus recorded by Pliny, Istters 8.8 in the Imperial period.

${ }^{1 "} \mathrm{Ve} 2.33$; Ve 229 and U. Ciotti, La provenienza della iscrizione umbra conservata nel Museo Nazionale di Napoli e i resti di un tempio italico presso il confine tra Todi e Amelia, in Arch. Class., 43, $1991,535-551$.

1 Organic material in archaic Umbrian sanctuaries has received little attention. 
region ${ }^{12}$. Some sanctuaries were on hills or in less obvious positions in or near to settlement sites (whose occupation can be traced through funerary evidence) : this category includes the Rocca at Spoleto (Spoletium), Monte Santo at Todi (Tuder), Foligno (Fulginiae), Amelia (Ameria), Bettona (Vettona) where it was near to the cemetery, and possibly Assisi (Asisium).

As I have noted above, the structures of archaic sanctuaries are only known from a few excavations. All are simple in construction and form, with little architectural elaboration. They range from a basic dry-stone platform at $M$. Ansciano to the (foundations of) small sacella at $M$. Acuto and at Gualdo Tadino (Col di Mori). The most elaborate is that at Pasticcetto di Magione where the remains of a small structure, probably created to receive the water of a spring, have recently been excavated ${ }^{13}$. The presence of architectural terracottas and tiles suggests that this basin was covered with a small wooden building. Whether all " sanctuaries " where votive deposits were created had a man-made physical structure is uncertain, but it is worth noting that all those recently excavated (M. Acuto, M. Ansciano, Pasticcetto di Magione and Ancarano di Norcia) had some sort of structural remains, except at Grotta Bella, where the natural cave setting seems to have rendered this superfluous ${ }^{14}$. Sanctuaries were often positioned within areas of earlier frequentation : there were traces of (previous ?) fortifications at M. Acuto, Gualdo Tadino (Col di Mori), M. Subasio and Ancarano di Norcia and of Bronze Age habitation at the Rocca of Spoleto, M. Ansciano and Grotta Bella ${ }^{15}$. It is tempting here to draw parallels with the re-use of Bronze age sites in Greece during the eighth century $\mathrm{BC}$, where the antiquity of Mycenaean tombs apparently served to legitimate actions several hundred years later, as well as with the re-use of an archaic tumulus tomb as the "heroon of Aeneas " at Lavinium in the fourth century $\mathrm{BC}^{16}$.

A range of different types of votive were left at these sanctuaries in the archaic period. Small human and animal figurines in bronze, rarely over 30 $\mathrm{cm}$ in height and usually under $10 \mathrm{~cm}$, were always by far the largest component of votive material ${ }^{17}$. The most common representations are of warriors

12 Intriguingly, Livy notes Roman action in $303 \mathrm{BC}$ against a group using a cave in Umbria as a military base (10.1.4-5 : quod nuntiabatur ex spelunca quadam excursiones armatorum in agros fieri), a function reminiscent of the role of sanctuaries such as Pietrabbondante in the commemoration of military victories (E. Dench, From Barbarians to New Men, Oxford, 1995, 138-40).

${ }^{13}$ P. Bruschetti, Il santuario di Pasticcetto di Magione e i votivi in bronzo, in Antichità dall'Umbria a Budapest, 113-23.

${ }^{14}$ It is of course much more difficult to recognise cult sites archacologically as such if they only have a small amount of votive material and no physical structures.

${ }^{15}$ The fortifications are themselves undated, but are known to be connected to Bronze Age material at M. Ansciano, and archaic cemeteries at Colfiorito. For Bronze Age frequentation see M. C. de Angelis, D. Manconi, I ritrovamenti archeologici sul Colle S. Elia, in La Rocca di Spoleto. Studi per la storia e la rinascita, Spoleto, 1983, 19 ; Monacchi, Grotta Bella, 76 ; Territory, Time and State (on Gubbio).

${ }^{16}$ On this shrine, see P. Sommella, Heroon di Enea a Lavinium, in $R P, 44,1971-1972,47-74$.

${ }^{17}$ On all the types of these figures see Colonna, Bronzi votivi. He has categorised the votives into groups according to their stylistic affinities, and labelled the groups with one of its constituent's find sites, even if this is not always their likely place of manufacture (c.g. the "Esquiline " 
(called the "Mars in Assault " type by Colonna) and what are conventionally called " oranti ", or worshippers (male and female figures with outstretched arms) $)^{18}$. Other types include figures identified as " Hercules", walking figures, " dancers", and " offerers "; besides these are found representations of parts of the body, usually limbs, and of animals, including pigs, oxen, goats and sheep. The figurines are almost exclusively made from bronze ; a few lead figures are known from Grotta Bella but they probably belong to a later phase of Umbrian production for which there is no evidence outside the territory of Amelia. The metal for the votives presumably came from the well known sources in western Etruria ${ }^{19}$.

The execution of locally produced bronze figurines is always stylized, and seems mostly to derive from earlier Etruscan types ${ }^{20}$. The representations vary from refined works to pieces of extreme simplicity : the dominance of schematic figurines in votive deposits is characteristic of sites in and bordering on the Umbrian region. These were produced in huge numbers (e.g. the 1600 examples found at $M$. Acuto) by a process of casting and then filing, and probably originate in workshops throughout Umbria. Anatomic details such as eyes, nipples, hands and so on were depicted by punched circles or incised grooves. Less commonly, schematic figurines are found made from sheets of bronze cut into representative shapes ${ }^{21}$. Not all the votives deposited in Umbrian sanctuaries were produced in the region. A few of the finest pieces, such as the Mars of Todi, were imported from Etruria, in this case from Volsinii.

The typology of the votives used may offer some clues as to the nature of the cult. Why were certain forms reproduced by Umbrian workshops and chosen by those using the sanctuary to leave there ? Monacchi has suggested that bronzes of animals, found widely in votive deposits of the Appennine areas of central Italy, are substitutes for sacrificial animals, as well as being thank-offerings for the protection of the donor's herd ${ }^{22}$; they are also a clear manifestation of the interest of this society in stock-raising. Importance is often attached to representations of warriors in an attacking pose, usually interpreted as representing Mars, a god who (as is well known) has strong agricultural and pastoral, as well as warlike, associations. It is possible that these warrior types were chosen by visitors to the sanctuaries as representing them-

group was probably produced in southern Umbria). See also E. Richardson, Etruscan votive Bronzes. Geometric, Orientalizing, Archaic, Mainz am Rhein, 1983, and Bronzes from Umbria, in Antichità dall'Umbria a Neu'York, 193-7.

${ }^{18}$ The presumed male figures generally have projections representing their sexual organs, the presumed female figures wear long clothing of some sort.

${ }^{19}$ On this area as the source of metal in the Bronze Age sec Territory, Time and State, 137 ; the variety of bronze metalwork from this earlier era found by the Gubbio project (illustrated 134-9) provides an important backdrop to the archaic production discussed in this article.

20 Colonna, Bronzi votivi, 23-4 ; E. Richardson, Bronzes from Umbria, 193-7.

${ }^{21}$ Colonna, Bronzi ıotivi, 105 : this technique probably originated in Latium ; cast bronze figurines of the Esquiline group seem to have passed in the other direction, from Umbria to Latium.

22 Grotta Bella, 80-81. 


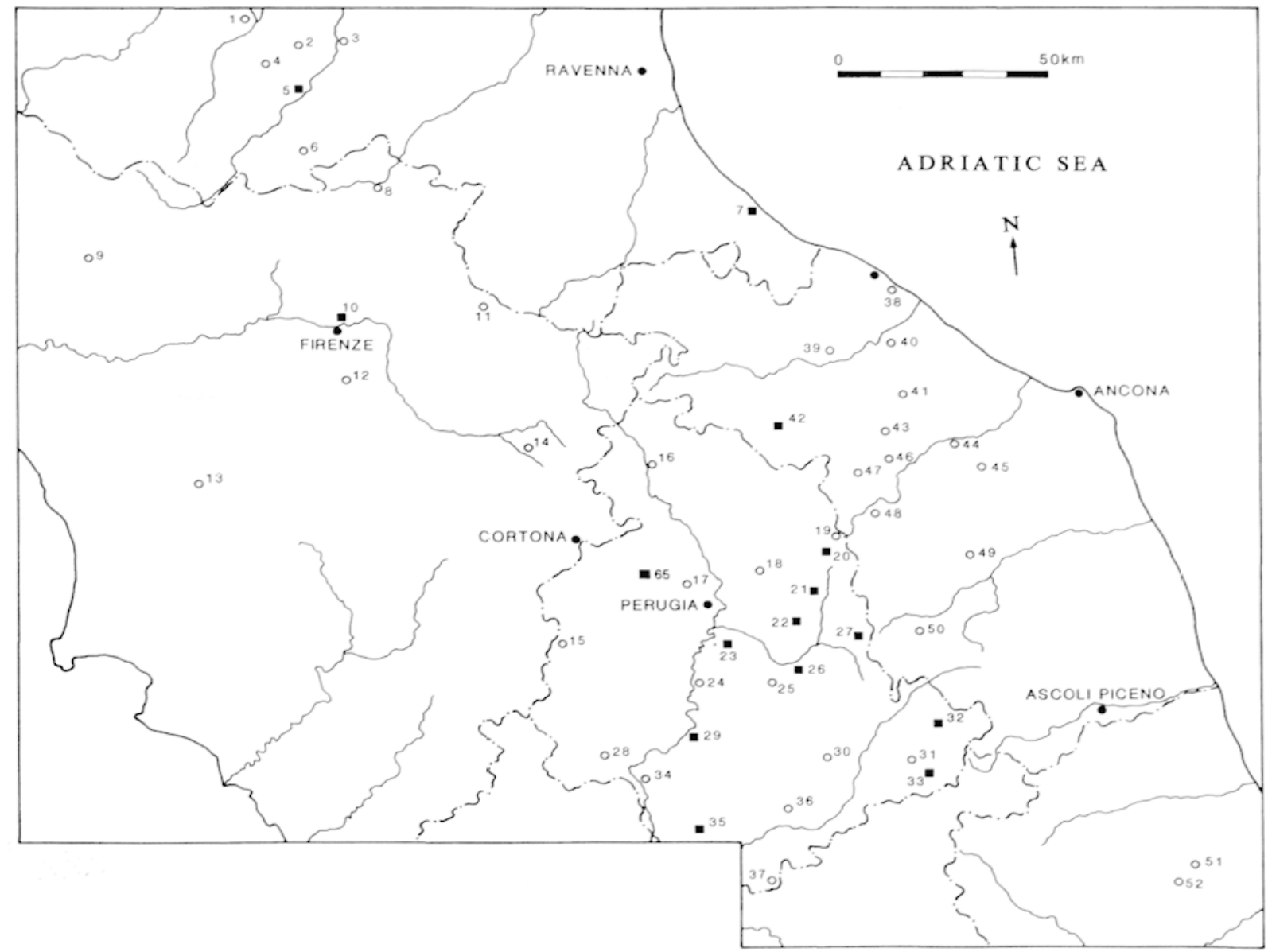

Map 1 : Provenances of Umbrian Type Bronze Votives (after G. Colonna, Bronzi votivi umbro-sabellici a figura umana 1. Periodo " arcaico", Florence, 1970)

$O$ Isolated and small finds

- Numcrous finds (medium and large deposits)

- Museums holding statuettes of probable local or regional provenance

1 Spilamberto

2 Zola Predosa

3 Bologna

4 Castello di Serravalle

5 Marzabotto

6 Grizzana (Monteguragazza)

7 Rimini

8 Firenzuola

9 Ponte a Moriano

10 Fiesole

11 Stia (Falterona)

12 Impruneta

13 Volterra

14 Arezzo

15 Chiusi

16 Città di Castello

17 Perugia (Colle del Cardinal)

18 Fratticciola Selvatica

19 Fossato di Vico

20 Gualdo Tadino

21 Nocera Umbra (Campo La

Piana)

22 Assisi (M. Subasio)
23 Bettona

24 Collazzone

25 Bevagna

26 Foligno

27 Colfiorito

28 Orvieto

29 Todi

30 Spoleto

31 Cascia

32 Ancarano di Norcia

33 Cascia (Valle Fuina)

34 Baschi

35 Amelia

36 Cesi

37 Calvi dell'Umbria (M. S. Pancrazio) 38 Novilara

39 Isola di Fano

40 Orciano

41 Castelleone di Suasa

42 Cagli

43 Arcevia (Montefortino)

44 Castelbellino

45 Staffolo
$46 \mathrm{~S}$. Fortunato di Genga

47 Sassoferrato

48 Fabriano

$49 \mathrm{~S}$. Severino Marche

50 Pievetorina

51 Penne

52 Montebello di Bertona

Additional sites (marked only on map 2):

$53 \mathrm{M}$. Loreto

54 Gubbio (Guastuglia)

55 Gubbio (M. Ingino)

56 (iubbio (M. Ansciano)

57 M. Acuto

58 Arna

59 M. Pennino

$60 \mathrm{M}$. delle Civitelle

61 M. Maggiore

62 Castel Ritaldi

63 Grotta Bella

$64 \mathrm{M}$. Torre Maggiore 


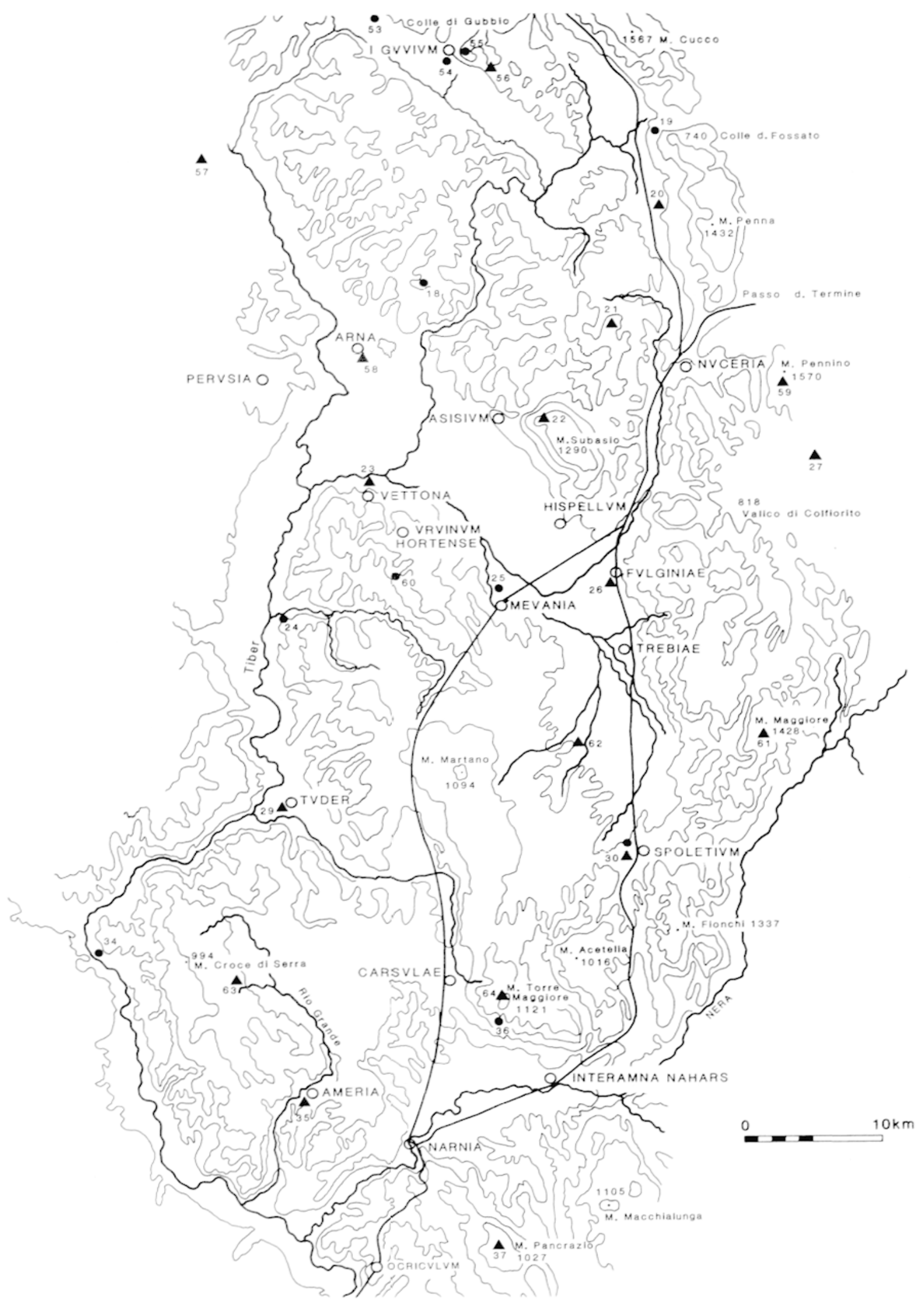

Map 2 : Sanctuaries in western Umbria, 600-100 BC (after P. Fontaine, Cités et Enceintes de L'Ombric Antique, Brussels-Rome, 1990, with additions)

- Isolated and small finds

$\Delta$ Numerous finds (medium and large deposits) 
selves, in the same way that the worshipper types (typified by the "Esquiline" group) seem to do. Votives of anatomic parts could have health-giving connotations, as is thought to be the case with anatomical terracottas, but this might not have any implications for the nature of the sanctuary in which they are found ; they usually make up only a small proportion of the votive material.

It is difficult to be precise about the exact proportions of the schematic to the more refined figurines deposited, because all the sites were plundered before being fully excavated, and the pieces of higher artistic quality will have been much more attractive and obvious (given that they were generally larger) to " clandestini ". Nevertheless, from the limited data available it is clear that the more sophisticated figurincs usually made up an extremely small percentage of the total numbers discovered. At Grotta Bella, for instance, there was one slightly more elaborate Mars figure of Colonna's "Nocera Umbra " group with 280 extremely simple figurines of the "Esquiline " group, and fifteen small animal bronzes of similar workmanship. The 65 figurines found in a scatter across the stone platform of $\mathrm{M}$. Ansciano were all of types classified as schematic by Colonna, made up almost totally of the basic "Esquiline " group, with only three more sophisticated " Mars " figurines of the "Foligno" and "Nocera Umbra " groups ${ }^{23}$. The huge numbers of schematic figures and the scarcity of the more refined bronzes are often assumed to be a sign of mass participation in the religious activity ${ }^{24}$. The schematic works could on this interpretation have been left by those of limited economic means, whereas the higher quality figures were designed for a small elite, with much greater disposable wealth. It is also possible, however, that all the votives were made for aristocratic use, perhaps with individuals leaving many votives each ${ }^{25}$.

Besides the ubiquitous bronze figurines some other types of material occur in the votive deposits of this region during the period before the Roman conquest. Large amounts of unworked bronze have been found at some sanctuaries, most notably the 40 kilograms from Ancarano di Norcia ${ }^{26}$. That excavated at Grotta Bella included two pieces marked with a lunar crescent and a star, which must represent an early attempt to create a standardised sign of value, although who was responsible, whether a private individual or a representative of a community remains uncertain. Archaic fictile material was also found at some cult sites, although it is less common than might be expected. This could be because its presence has gone unremarked at many sites. At $M$. Ansciano, a few pieces of decorated terracotta, including one representing a head, were found along with bronze votives and may have served the same purpose as them according to the excavators ${ }^{27}$. Nevertheless, even bearing in

23 Territory, Time and State, 145-52.

${ }^{24}$ E.g. P. Bruschetti in Antichità dall'Umbria a Budapest, 114.

${ }^{25}$ Monacchi, Grotta Bella, 96, noting the intrinsic value of the metal used for the votive figurines and of the unworked bronze left at this site.

26. Schippa, Il deposito votivo di Ancarano di Norcia, 206 ; see also Amelia : G. Eroli in Bull. Inst. (1864) 56-9. This material cannot be dated with any certainty.

${ }^{27}$ Territory, Time and State, 145. 
mind possible biases in our information, the preference of the users of Umbrian sanctuaries for locally produced bronze figures (surely designed for this purpose) over goods made from other materials and/or imports, is stri$\mathrm{king}^{28}$. This strongly suggests that the figurines did have a symbolic meaning of some kind.

It is difficult to reconstruct how this votive material was used at these cult sites without a good idea of what form the structures created there took ${ }^{29}$. The votives themselves seem often to have been designed for fixing onto a surface for display. Higher quality figurines have downward pointing spurs from their feet (or the lower surface of anatomic pieces without feet) ; in simpler examples the legs end in spikes with no attempt to represent feet. Some votives consist merely of heads with spikes projecting below. Stoddart and Whitley have suggested that the 169 nails found in a "broadly similar " distribution to the bronze and terracotta votives across the stone platform at $\mathrm{M}$. Ansciano were used to attach the figurines and fictile pieces to a wooden screen or the trees of a natural grove ${ }^{30}$. But this seems unlikely for all the votive figurines because some of them have no possible nail holes. Direct fixing of the votives into the wood must be more probable; the nails could have instead been used for creating some sort of frame into which the votives could be stuck.

The excavators of $M$. Ansciano have also attempted to estimate the level of activity at this site by placing the number of votives (65) against the minimum 200 year usage of the sanctuary in the archaic period, surmising that if the number of figurines excavated was "approximately representative ", the rate of activity was " very low ". The votives were found, however, scattered across the stone platform, which implies they were those which had fallen off the screen at some point and failed to be recovered during the subsequent use of the site ${ }^{31}$ : the number of votives would not in this scenario be representative of the overall frequentation of the site. Excavations where material is found buried in votive deposits may give a more useful impression : these regularly contain hundreds of figurines $(1600$ were found at M. Acuto, in spite of earlier illegal excavations). Nevertheless, we still do not know what these accumulations really represent, whether they were portions of the votive material once present, or all of it, material collected over a short space of time or a long period of years, and so on. In fact, any sort of conclusion based on absolute numbers of votives appears fragile, given the circumstances of their recovery.

${ }^{28}$ That imports, c.g. Greck and Etruscan pottery and bronzes, were available is clear from funcrary evidence (see Bonomi Ponzi in Antichità dall'Umbria a Budapest, 40).

2" For a definition of why this should be regarded as " ritual " behaviour, see Stoddart and Whitley in Territory, Time and State, 142-3; they emphasise the repetitive nature of votive deposition, the use of distinctive bronze figurines and the demarcation of the cult area. We can also note the association of figurines with the inscribed dedication to the deity Cupra at Colfiorito.

311 Territory, Time and State, 145 . How any screen or grove related to the stone platform is unclear ; no dateable post holes were found.

${ }^{31}$ This continued (perhaps sporadically) until the Late Imperial period. 


\section{Sanctuaries and settlement}

In working out the possible role of sanctuaries within this society, we can draw on the typology of the votives and on the topographical position of the sanctuaries, but should also consider the settlement pattern within the region. Several different interpretations have been put forward. Bonomi Ponzi suggests that the forms of the votives and position of the sanctuaries are strongly linked to aristocratic ideology and self-justification ${ }^{32}$. The sanctuaries provided political and economic centres in the absence of urban agglomerations. For Monacchi, M. Subasio is typical of the sanctuaries of the Umbrian Appennines in providing a mecting point betwecn the stable population in the area and transhumant groups, within a society that is "based prevalently on a pastoral economy " ${ }^{3.3}$. Two wider assumptions are common to most approaches to these sanctuaries : firstly, that their position is conditioned by communications routes, which supposedly run close to all cult sites ; secondly, that the votive typology, simple structures and rural positions of these sanctuaries is indicative of a "pagano-vicano " type of settlement.

In my opinion, however, this picture of Umbrian society and the sanctuaries it produced tends to be an oversimplification of a more complex situation $^{34}$. Umbria is a varied region in geographical terms, including both high mountain areas analogous to other stretches of the Appennines to the north and south, as well as the less elevated hills, valleys and plains of the subAppennine area. In the full Appennine zone, the well investigated settlement system based around the upland basin at Colfiorito does indeed show clear parallels with the situation elsewhere in the Appennines ${ }^{35}$.The sanctuary here, in which a dedication to Cupra was found (Po 2), was situated on the shores of a lake (now drained) and was on a major route from Umbria to Picenum ; it was near the large hillfort on $M$. Orve and its important corresponding cemetery at Colfiorito ; many other smaller hillforts, often with their own corresponding cemeteries, were sited on the surrounding mountains.

Other sanctuaries were sited according to different priorities. The clearest contrast is offered by the presence of cult sites in or next to settlement centres at Todi (Tuder), Spoleto (Spoletium), Amelia (Ameria), Foligno (Fulginiae) and possibly Assisi (Asisium) ${ }^{36}$. The presence of early votive deposits implies

32 Antichità dall' Umbria a Budapest, 42-3. She sees the warrior figurines as symbolic of an aristocratic military ethos, and animals as symbolic of the ultimate basis of elite wealth.

${ }^{3.3}$ Monacchi, Monte Subasio, 81.

34 The terms pagus and vicus seem rare in the epigraphy of this region. Pagus is attested at Cesi (C. Bucttner, L'abitato umbro di Cesi e il santuario di S. Erasmo, in AFLP, 25, 1987-1988, 55, perhaps relating to (arsulac); a ir(ibunus) (CIL I $\left.\mathrm{I}^{2} 2106=I L L R P, 668\right)$ from the territory of Spoleto was a magistrate of a pagus or vicus in the opinion of 1)egrassi (ILLRP, 2 p. 117).

35 L. Bonomi Ponzi, Topographic survey of the Colfiorito di Foligno plateau. A contribution tourards the study of the population in the territory of the Plestini, in C. Malone and S. Stoddart (eds.), British Archaeological Reports, Papers in Italian Archaeology, 4. Oxford, 1985, 201-38.

36 For the first four sites see Colonna, Bronzi votivi ; see also M. Torelli, La società della frontiera, in Todi. Verso un museo della citta. Mostra degli interventi sul patrimonio archeologico, storico, artistico di Todi, Exhibition cataloguc, Todi, 1982, 54-8; L. Bonomi Ponzi et al., Spoleto. Da villaggio a 
that these settlements already had a religious function in the archaic period. At Gubbio (Iguvium) the use of the sanctuary on M. Ansciano by the community centred on the later Roman city site post-dates the use of the hillforts by at least 300 years ${ }^{37}$. The close proximity of a mountain sanctuary to an early lowland settlement is also apparent at Assisi, where the cult site of $M$. Subasio is on the nearest peak of the massif to the settlement. Other possible pairings could include M. San Pancrazio and Otricoli (Ocriculum), and M. Torre Maggiore and Terni (Interamna Nahars) ${ }^{38}$. The centrality of the ocar/ukar (Latin arx) within the rituals of the Iguvine Tables could be tentatively invoked here, although it remains uncertain whether this refers to a mountain or simply a high point within the settlement ${ }^{39}$. In the Tables the ocar fisio is continually paired with the Iguvine tota, usually in the formula ocriper fisin totaper iouina, roughly translatable as " for the Fisian Mount, for the Iguvine community ". I would not want to claim that this pairing was the fundamental pattern of settlement and sanctuary, but would simply stress that there were a variety of possibilities in this region, due to the variety of settlement organisations.

Grotta Bella seems to demonstrate another of these possibilities. Distant from the nearest nucleated settlements at Amelia and Todi, and not on any important through route, it was surely used primarily by the farmers and herdsmen of the agricultural land to the east and the mountains lying to the west of it, rather than by passing trade : the site must have been chosen for its striking natural cave setting ${ }^{40}$. The hillforts on the summits of nearby mountains, if frequented in the same era as the sanctuary, could have provided a refuge for the same population.

\section{Sanctuaries and the "state"}

Studies of the development of social complexity in areas of the eastern Mediterranean have highlighted the importance of the beginning of ritual

città, Exhibition catalogue, Perugia, 1989, and M. C. 1)e Angelis (ed.), Spoleto. Il colle della Rocca. Primi risultati di scavo, Exhibition catalogue, Perugia, 1994 ; Amelia : G. Eroli in Bull. Inst., 1864, 56-9 ; 1867, 171 ; Assisi : M. Tomei, Lo seavo di via Arco dei Priori ad Assisi in Les "Bourgeoisies" Municipales Italiennes aux Ile et Ier Siècles at. J.-C., Congress, Paris-Naples, 1983, 393-5.

37 Territory, Time and State, 113, 145.

${ }^{38}$ For M. San Pancrazio sec R. Paribeni, in Scritti in onore di B. Nogara, 1937, 359-6.3 ; U. Ciotti, Nuove conoscenze sui culti dell'Lmbria antica, in I problemi di storia e archeologia dell' Lmbria. Atti del I convegno di studi umbri, Congress, Gubbio-Perugia, 1964, 110-11 ; for M. Torre Maggiore see M. Gaggiotti, D. Manconi, L. Mercando, M.Verzar, Lmbria Marche, Guida archeologica Laterza, Rome-Bari, 1980, 128-9.

39' The term is discussed by A. Prosdocimi, Il lessico istituzionale italico. Tra linguistica e storia, in La cultura italica, Pisa, 1977, 37-9.

+1" It is hard to think of anywhere in southern Umbria which would be further from communication routes, except for the very tops of mountains, where there are also archaic sanctuaries, such as M. San Pancrazio near ()tricoli. Conversely Monacchi sees Grotta Bclla as in a zone of " percorsi fondamentali dell'Umbria meridionale ", as well as serving the surrounding agricultural community (Grotta Bella, 95). 
activity in sanctuaries ${ }^{41}$. The appearance of sanctuaries implies the designation of spaces for ritual activity. This, and the development of specialised types of votives, suggests that communal thinking and activity is becoming more compartmentalised and organised. Involvement in rituals helps to bring together and define, as well as bind, groups of people ; the articulation of such groups is essential for the organisation of communities. Thus the use of sanctuaries is often a sign of increasing communal organisation. The monumentalisation of sanctuary sites, usually in the form of temples, can represent another important stage in terms of communal action, and a commitment of greater collected resources (even if in the hands of just a few individuals) than the simple deposition of votives.

Stoddart and Whitley have drawn attention to the suggestive parallel between the peak sanctuaries of Crete and Umbria in their work on Gubbio ${ }^{42}$. In Crete rural sanctuaries of the Middle Minoan period were generally situated on the summits of mountains, were of a simple structure, and contained deposits of clay votive figurines representing people, animals and human limbs. The creation of these sanctuary spaces coincides with the decline in the use of large tholos tombs as sites for rituals (probably based around clan organisation). This shift in the focus of activity is connected with the changes in society that lead to the growth of larger palatial and urban settlement centres, although this latter development may not occur until several generations later ${ }^{43}$. The appearance of peak sanctuaries is a first symptom of the process that will lead to such states on Crete. For Peatfield they represent the "religious dimension to this growth of a larger community identity ", as "small independent settlements of the Prepalatial period gave way, in the Palatial period, to larger regions of economically and politically interactive settlements focused on the palatial and urban centres ${ }^{44}$.

The peak sanctuaries seem to undergo two phases of development. The first was characterised by the creation of at least twenty-five sites in the Early Minoan period ; in the second phase all but eight fell into disuse. Peatfield has argued that the second phase is the point at which the sanctuaries came directly under the control of the elite of the palatial centres, and were used by the palatial elite as part of a new centralised religious system.

These parallels with other (often very different) societies do not by themselves show what is happening in Umbria in the period in which votive deposits appear, but what they can do is to suggest some of the approaches we

${ }^{41}$ E.g. A. Snodgrass, Archaic Greece : the age of experiment, London, 1980, 33, 52-65 ; F. de Polignac, La naissance de la cité grecque, Paris, 1984 ; J. Cherry, Polities and palaces : some problems in Minoan state formation, in C. Renfrew, J. Cherry (eds.), Peer Polity Interaction and Social Change, Cambridge, 1986, 19-45 ; S. Alcock, R. Osborne (eds.), Placing the Gods. Sanctuaries and Sacred Space in Ancient Greece, Oxford, 1994.

42 Territory, Time and State, 142-152.

${ }^{43}$ A. Peatfield, After the "Big Bang" - uhat? or Minoan symbols and shrines beyond the palatial collapse, in Placing the Gods, 23. This is strongly disputed by Cherry who states that " attempts to push back the history of peak sanctuaries into the pre-palatial period ... involve stretching the defining criteria to an unacceptable degree "(Polities and palaces).

${ }^{44}$ A. Peatfield, Minoan peak sanctwaries : history and society, in Opuscula Atheniensia, 17, 1990, 125. 
might adopt towards the Umbrian evidence. A detailed examination of the other trends in the archaeology of Umbria in the archaic period goes beyond the scope of this article, but we can briefly note the following. We can point to the emergence of an elite, judging by the extremely rich tombs with characteristically aristocratic accoutrements (such as symposion equipment, Greek vases and in some cases chariots) that appear from the end of the seventh century onwards in the better known cemeteries in Umbria, among them Todi (Tuder), Colfiorito (Plestia) and Monteleone di Spoleto ${ }^{45}$. The use of sanctuaries throughout the region (at least for depositing votives) begins in the late sixth and fifth century. There is little sign of different building phases at most sites, although this could largely be the result of the limitations of our excavated evidence. In the fourth century, the erection of monumental buildings, probably with a religious function, in settlement sites and the building of fortifications around some of these places (both trends that are likely to stem from contact with the urbanised Etrusco-Faliscan region), provides additional evidence for cooperation within communities ${ }^{46}$. It is this, rather than any further building on the site of rural sanctuaries, that seems to become the most important focus for the wealth and activity of Umbrian communities. The fifth and fourth century is also the period in which there is the first evidence of the ethnic identities of the population(s) of the region : the Umbrians as a whole are recorded in Greek authors such as Herodotus, and in the earliest epigraphic material there is a record of smaller ethnic divisions $^{47}$. But attaching significance to the use of these ethnics is problematic, as their appearance may be largely conditioned by the availability of a medium for expression, whether writers from outside or epigraphy from inside the region.

\section{$V$ Umbrian religious practice from the Roman conquest to the Augustan era}

In this section I want to follow the changes that occur to these sanctuaries and the cult activities that took place there in the period after the Roman conquest. Perhaps the most important question to be addressed is to what extent the changes are a result of either the new Roman presence in and control over the region, or of the development of temples within settlement centres in the last centuries of the Republic. The latter can be documented

${ }^{45}$ On this period in Umbria see L. Bonomi Ponzi, Aspetti dell'orientalizzante nell'Umbria appenninica, in M. Corbucci, S. Pettine (eds.), Gens antiquissima italiae : Antichità dall'Umbria a Leningrad, Exhibition catalogue, Perugia, 1990, 118-19.

46. Temples are known from architectural terracottas at Bevagna (A. Feruglio, L. Bonomi Ponzi, D. Manconi, Mevania. Da centro umbro a municipio romano, Perugia, 1991, no. 2.37), Todi (Todi. Verso un museo, Exhibition catalogue, Todi, 1982, 125, 138), Gubbio and Civitella d'Arno (ancient Arna) (M.J. Strazzulla, Le terrecoite architettoniche: le produzioni dal IV al I ser. a.C., in Società romana e produzione schiavistica, II, Bari, 1981, 196). Fortifications : P. Fontaine, Cités et Enceintes de L'Ombrie Antique, Brussels-Rome, 1990.

${ }^{47}$ Po 1 and 2. 
by architectural terracottas ${ }^{48}$. Previous work has linked the Roman presence to a decline in the use of rural sanctuaries. M.Verzar has pointed to the abandonment of sanctuaries in more Romanised areas, for example M. Subasio and M. San Pancrazio and to the prolonged use of those in the Appennine zone, for example Gualdo Tadino (Col di Mori) ${ }^{49}$. To those she classifies as abandoned we might add the sanctuary of Campo la Piana near Nocera Umbra, where there is no votive material from after the second century. In the other direction, there is also evidence of prolonged frequentation into at least the first century $\mathrm{BC}$, if not the imperial period, at $\mathrm{M}$. Torre Maggiore, Grotta Bella, M. Ingino, M. Ansciano, M. Acuto, and Colfiorito.

But there are problems with this sort of approach. Firstly, it is difficult to be certain about levels of frequentation of rural cult sites. Only a small number of them have dated building phases, and in most cases we are reliant on the quantity of votives found. We can only assume that the deposition of votives roughly reflects the level of activity, and that no votives at all mean that the site was abandoned. We can never actually rule out the possibility that activity continued on a site in a way that has left no archaeologically visible traces. Secondly,Verzar's view does not take any account of the changing proportions of material found on these sites in different chronological periods. Most sanctuaries are poorly documented ; we only get anything approaching a representative picture from the handful of sites which have been both recently excavated and fully reported. We can take $M$. Ansciano as an exemplar of these, although it should be borne in mind that the artefacts and remains found here were not elaborate by the standards of most Umbrian sanctuaries $^{50}$. If we judge frequentation by the quantity of votive material found, there seem to be substantial shifts in the patterns of its usage. The excavators date the most intense phase of use of the sanctuary to a period between the late sixth and third centuries $\mathrm{BC}$, following the work of Colonna on the style of the votive figurines discovered ${ }^{51}$. The material from after this period is less significant in quantity, although it shows that the site continues to be frequented, presumably still with a continuing ritual purpose. Instead of bronze figurines, Roman Republican coins and numerous fragments of Imperial cups and lamps are found. The pattern at $M$. Ansciano of a most intensive phase of usage down to the fourth/third century, followed by a reduced, but continued frequentation may be common to other less well investigated sites.

${ }^{48}$ There is no convenient summary of this evidence, although Strazzulla, Le terrecotte architettoniche, collects much of it ; besides those sources listed in n. 46 above, see Spoleto Rocca. Primi risultati, 20-2 ; M. Matteini Chiari, Raccolta di Cannara : materiali archeologici, monete, dipinti e sculture, Perugia, 1992, 64ff. (on Urvinum Hortense) ; M. J. Strazzulla, Assisi. Problemi urbanistici, in Les "Bourgeoisies" Municipales Italiennes aux Ile et Ier Siècles av. J.-C., Congress, Paris-Naples, 1983, 153.

49 M.Verzar, La situazione in Umbria, in Società romana e produzione schiavistica, I, Bari, 1981, 373 , using the evidence for the deposition of votives.

50 Territory, Time and State, 145-52.

${ }^{51}$ But Colonna, Bronzi votivi, 24, states that most production ends in the early fourth century $\mathrm{BC}$. 
In other words, the mere presence of later Republican material noted in less detailed reports may actually mask a decline in use. Most summary accounts simply fail to acknowledge this.

This pattern is paralleled in other sanctuary excavations. At Pasticcetto di Magione, the most intense phase of activity seems to have been from the fifth to the third centuries $\mathrm{BC}$, judging by the typology of the bronze votive material and the architectural terracottas ${ }^{52}$. The presence of some black glaze and terra sigillata pottery shows that frequentation of the site continued into the imperial period, although this was probably only on a sporadic basis. The same pattern of offering - regular in the period before the conquest, but tailing off in the third or second century $B C$ - has been ascribed to the sanctuary on M. Subasio ${ }^{53}$. Unfortunately only nine small bronzes from the votive deposit discovered here in 1879 have been preserved and recorded, and so we cannot be absolutely sure that significant quantities of later material were not also present, especially considering that late Republican material has been found at all the sites excavated in the last twenty years. The various statuettes, the later examples of which may not have been produced in Umbria, have been assigned by Monacchi on the grounds of style to various dates from the end of the sixth or start of the fifth century to the third or second century BC. It is tempting to connect the apparent ending of ritual activity here and the decline of that at $M$. Ansciano to the beginnings of evidence for temple building in the centres of Assisi and Gubbio ${ }^{54}$. But without better information on M. Subasio we need to be cautious in identifying this sanctuary as part of a general trend.

By contrast there are other sanctuaries in Umbria where frequentation. as far as we can tell, does not show a serious decline in connection with the Roman conquest. The best known of these is in Grotta Bella, excavated from 1970 to 1974 , after " clandestine " activity had seriously damaged the stratigraphy ${ }^{55}$. Of the material that remained, the largest quantity was from the pre-Roman period (304 bronze and lead votives) but a considerable amount belonged to the $300-90 \mathrm{BC}$ period. The latter was more varied than the former, including pottery, four anatomic votive terracottas and 97 bronze coins, of which the largest number were from the second century. There is a gap in the evidence from the Social War to the first century AD, probably as a result of the site's abandonment, and thereafter only sporadic evidence for use of the site until the fourth century AD has been recovered. The results of this excavation would seem to suggest that not all rural sanctuaries went out of use in the period around the Roman conquest. Clearly the frequentation of Grotta Bella in the third and second centuries $\mathrm{BC}$ remained at a much higher level than that of comparable sanctuaries at $M$. Ansciano and Pasticcetto di Magione. The continued use of the sanctuary at Ancarano di Norcia, in this

\footnotetext{
52 Bruschetti in Antichità dall' Umbria a Budapest, 113-23.

53 Monacchi, Monte Subasio ; Helbig, Bull. Inst., 1880, 249-5(), noted the presence of archaic bronze votives and ceramic fragments.

${ }^{54}$ For the architectural terracottas at Gubbio and Assisi see n. 46 and 48 below.

55 Monacchi, Grotta Bella.
} 
period parallels that of Grotta Bella ${ }^{56}$. This example might suggest that it was the position of such sanctuaries away from developing urban centres in wholly rural districts, that ensured their longer-term survival.

Two other sanctuaries show some evidence of continued use. A Roman statue and base and large numbers of votive bronzes turned up within or next to the enclosure of the sanctuary at Gualdo Tadino (Col di Mori), whose form was clarified by superficial excavation in the early $1930 \mathrm{~s}^{57}$. The intensity of its use in the Roman period remains unclear, however, without more detailed archaeological information. In addition, Roman era material was also found in the excavation during the 1960 s of the sanctuary at Colfiorito ${ }^{58}$. The ancient city of Plestia grew up within a kilomctrc of this sanctuary, probably over the last three centuries of the Republic and with Roman rather than allied status. The results of the excavations have only been briefly summarised, unfortunately, and we can say little more than that the sanctuary continued in use between the fifth and first centuries BC, with all the attendant problems, discussed in relation to $\mathrm{M}$. Ansciano, of what this actually means.

Further evidence of the religious changes in this period come from the votive deposits themselves. There is a dramatic change from the period before the Roman conquest, when they consist almost totally of bronze figurines, to after, when coins, and fictile products like pottery usually predominate, with bronze only in much smaller quantities ${ }^{59}$. The later fictile material includes some votives imitating anatomic forms. These are typical of Latium, Etruria and Campania and their presence in Appennine central Italy is often taken as a sign of Romanisation. Does this mean that where they occur Umbrian cult practices of the pre-conquest period had been replaced by Roman inspired forms of dedication?

The exact significance of this change in Umbria seems hard to pin down. It is not at all clear that the ending of Umbrian production of bronze figurines is connected to the Roman conquest. Such bronzes have not been excavated from stratigraphic contexts, and have to be dated on the basis of style. Colonna, in the standard work on Umbrian votive bronzes, says that their manufacture becomes sporadic after the early fourth century $\mathrm{BC}$, although that of schematic figures could continue for a longer period ${ }^{60}$. Other writers, such as $M$. Verzar, have taken the Roman conquest as the most significant break $^{61}$. In fact fitting these extremely simple works into a preconceived cannon of ancient art is very problematic.

${ }^{56}$ D. Manconi, M. De Angelis, Il santuario di Ancarano di Norcia, in DdA, 1, 1987,17-28.

57 E. Stefani, in $N S c, 1935,155-173$.

58 Ciotti, Nuove conoscenze, 99-112. When Ciotti wrote this the excavations had been suspended (104), after obtaining only provisional results, and have since focused on the necropolis area.

${ }^{59}$ This ceramic material is usually either produced in Roman (and Etruscan) areas or consists of local imitations of their forms.

${ }^{60}$ Colonna, Bronzi votivi, 24.

${ }^{61}$ M. Verzar, Archaologische Zeugnisse aus Umbrien, in Hellenismus in Mittelitalien, Göttingen, 1976, 119. 
After the conquest terracotta votives appear in some deposits but only in small numbers. Just outside Amelia three anatomic votives and fifteen terracotta heads were found together with coins and a large number of bronze as well as some lead figurines in the $1860 \mathrm{~s}^{62}$. A votive deposit found in the late nineteenth century in association with a sanctuary at Campo la Piana near Nocera Umbra contained two terracotta heads as well as about 150 small bronzes $^{63}$. Within the same area, two votive terracottas are known to have come from Colle di Nocera to the north ${ }^{64}$. Similarly small proportions of anatomic votives to earlier bronze material have been discovered at Grotta Bella (discussed above) and at Isola di Fano near Fossombrone on the other side of the Appennines ${ }^{65}$. In addition one other site in Umbria has to my knowledge produced terracotta votives, this being Bevagna (Mevania). The civic collection of this town includes a mould for the production of terracotta feet, a terracotta head and a small terracotta altar, all of mid Republican date (third or second centuries BC) ${ }^{66}$. Do such small proportions of material indicate that these cults were now of a predominantly " health-giving " character, and does this represent a radical change from their earlier nature?

There are some similarities between the votive deposits of the fifth and fourth centuries and those of the period after the Roman conquest. Firstly, Umbrian sanctuaries such as $M$. Subasio, Todi and Nocera Umbra continue to receive offerings of different types of bronze figurines in the third and second centuries ${ }^{67}$. These figurines are common to a large area of central Italy and were not necessarily manufactured in Umbria, unlike the archaic figurines. Secondly, representations of anatomic parts already occur in archaic Umbrian votive deposits, cropping up at Bettona (Vettona), Arna, M. San Pancrazio and Todi, and outside Umbria at Pasticcetto di Magione and Fonte Veneziana (Arezzo) ${ }^{68}$. Obviously, these parallels should not be pushed too far, but we should note that the evidence of the votive material suggests a complex process of change rather than a simple replacement of an "Italic type " of cult with a "Roman type ".

In summary, there seems to be evidence that the creation of some sanctuaries in settlement sites in the fourth and third centuries, which we know from the evidence of architectural terracottas, did correspond to an apparent decline in use of rural sanctuaries of archaic origin. At some (perhaps most) rural sites, continuity of ritual activity after the Roman conquest was probably only on a sporadic basis ${ }^{69}$. This is the case with $M$. Ansciano and M. Subasio

6.2 G. Eroli, Bull. Inst., 1864, 56-9 ;1867, 171 ; Monacchi, Grotta Bella, 84 n. 47.

${ }^{6.3}$ L. Brizio, Nocera Umbra. Resti di un antico santuario risconosciuti in contrada Campo la Piana, in NSc, 1891, 308-313.

${ }^{64}$ L. Bonomi Ponzi et al., Il territorio nocerino tra protostoria e altomedioevo, Exhibition Cataloguc, Florence, 1985, 72.

${ }^{65}$ Bull. Inst., 1875, 75-81; NSc, 1899, 26()-1.

G. Mevania, 44-5.

${ }^{67}$ Find sites noted in Monacchi, Monte Subasio, 87 n. 53. These may not be produced in Umbria.

${ }^{6} 8$ Antichità dall' Umbria a Budapest, 122, 126.

69 On the assumption that the decline in the number of votives left is not wholly the result of a change in the pattern of offering. 
(although we are poorly informed on this excavation), both of which are near important centres ( $2 \mathrm{~km}$ from Gubbio and $3 \mathrm{~km}$ from Assisi respectively) where we have probable evidence for temple building in the fourth or third centuries BC. It thus seems likely that these new temples took over the function of the old mountain top sanctuaries ${ }^{70}$. A few other sanctuaries in more rural surroundings far from nucleated settlements, such as Grotta Bella, continued to be frequented on a regular basis down to the Social War, but even here the archaic phase was the period of greatest votive deposition. The archaeological evidence from all the excavated examples (at least) of rural sanctuaries in Umbria suggests they fell out of common use after the Social War.

The pattern of religious activity in all its archaeologically visible forms in Umbria during the third and second centuries BC shows an interesting contrast with the situation in other central Italian regions such as Samnium, and perhaps also Picenum (although the picture is less clear here). In Samnium, many rural sanctuaries, such as Pietrabbondante, Vastogirardi and Schiavi d'Abruzzo, are given a monumental dress in the third and second centuries. A similar wealth of building activity is evident in second century sanctuary sites in Picenum such as Colle San Giorgio and Monte Rinaldo ${ }^{71}$. Although it should probably not be assumed that these sanctuaries were wholly isolated from all settlement, or that Samnite settlements lacked religious buildings, there does seem to have been a general separation between the great rural sanctuaries and the settlements that became municipia after the Social War ${ }^{72}$. The contrast with Umbria is clear : here a considerable number of sanctuaries in or just outside towns seem to have been monumentalised in the third and second centuries, but virtually none in the countryside. Nevertheless the Umbrian picture is not entirely black and white : two rural sites, at the Lacus Clitumnus, and on the peak of $M$. Torre Maggiore, seem to have been well frequented in the first centuries $\mathrm{BC}$ and $\mathrm{AD}^{73}$. Their continuing use may be due to the establishment of close links with local municipia, certainly Hispellum for the Lacus Clitumnus and perhaps Carsulae or Interamna Nahars for $M$. Torre Maggiore ${ }^{74}$.

${ }^{70}$ The discovery of architectural terracottas and a votive deposit relating to a temple under Santa Maria in Camuccia at Todi (E. Fabbricotti, Ritrovamenti archeologici sotto la chiesa della visitazione di Santa Maria "in Camuccia ", in Res Tudertinae 10, Todi, 1969), shows that the deposition of votives was a part of the rituals at both types of site.

${ }^{71}$ L. Mercando, L'ellenismo nel Piceno, in Hellenismus in Mittelitalien, 171-2 ; G. Iaculli, Il tempio italico di Colle S. Giorgio (Castiglione Messer Raimondo), Castiglione Messer Raimondo, 1993.

${ }^{72}$ See J.-P. Morel, Le sanctuaire de Vastogirardi (Molise) et les influences hellénistiques en Italie centrale, in Hellenismus in Mittelitalien, 261-2 on possible traces of settlement around the temple at Vastogirardi ; cf. La Regina, 223, 247 in the same volume on a sacello " at Aufidena and the post Social War use of Pietrabbondante ; Dench, From Barbarians to New Men, 136-4i) on the functions performed by the major sanctuaries.

${ }^{73}$ At M. Torre Maggiore recent archacological work has uncovered a monumental complex with at least two phases of building activity, the later of which probably dates to the first century $13 C$.

${ }^{74}$ Pliny, Letters 8.8 records the attribution of the sources of the Clitumnus to Hispellum by Augustus. 


\section{Conclusion}

I will confine myself here to stressing some of the main themes of this article. Firstly the state of the evidence is such that we know very little about the rituals we assume were practised at these cult sites. It is clear, however, that many of the existing ideas about these sanctuaries, particularly concerning the relationship between cult sites and the pattern of the settlement in the region, underestimate the variation in this system across the region, and its differences from other areas of central Italy. In addition, the changes in the nature of votive deposits after the Roman conquest was a complex process probably only partially due to "Romanisation". In fact the shifts in emphasis of Umbrian religious practice from the fourth century $B C$ are likely to owe much to the creation of sanctuaries within settlements, in which internal forces certainly played a part. On a more positive note, parallels with Crete suggest that the appearance of sanctuaries on an impressive scale in archaic Umbria may be a sign of increasing communal organisation, and a reminder that the study of these sanctuaries should not be divorced from the study of the communities that use them. 